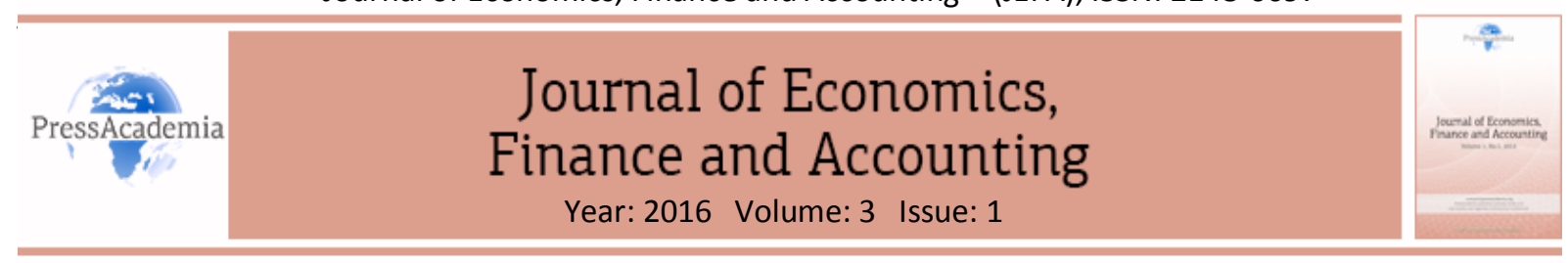

\title{
A COMPARATIVE BIBLIOMETRIC ANALYSIS OF FINANCE PAPERS PUBLISHED IN HIGH IMPACT JOURNALS AND DEVELOPING COUNTRY-ADDRESSED JOURNALS: THE CASE OF TURKISH JOURNALS
}

\section{DOI: 10.17261/Pressacademia.2016116534}

\author{
Sinan Esen', Hakan Tunahan', Davut TakıI ${ }^{3}$ \\ 'Sakarya University, sinanesen@sakarya.edu.tr \\ ${ }^{2}$ Sakarya University, htunahan@sakarya.edu.tr \\ ${ }^{3}$ Akyazı Ahi Evran Vocational and Technical College, davutr@gmail.com
}

\begin{abstract}
The aim of this study is to compare finance articles published in highest-impact journals and developing country-addressed journals from a bibliometric perspective. For this purpose, it compares finance papers published in the Turkish-originated journals Journal of Economics, Business and Finance (IIF) and Journal of Accounting and Finance (known as Mufad) with those published in the world's most influential journals, Journal of Finance (JOF) and the Review of Financial Studies (RFS), in terms of research collaboration, author self-citation, average length, average age of reference, and JEL category, for the period covering 2010-2014. Our results show that Turkey-addressed journals have a smaller average number of authors, number of references, and author self-citation compared with high-impact journals. However, we also observe in comparison that Turkish female academicians have made more contributions to the finance literature, and the average article length (in page numbers) is increasing in Turkish journals. Finally, Turkish academicians are more likely to be generalists, compared with Western Academicians, who tend to concentrate in narrower research fields.
\end{abstract}

Keywords: Finance studies, bibliometric analysis, comparative analysis, journal rankings, finance journals. JEL Classification: G00, M20

\section{INTRODUCTION}

One may argue that academic-finance-journal publishing began in 1917 in the United States, with the publication of the Federal Reserve Bank of St. Louis Review. Another pioneer was the Journal of Business, which began publishing in 1928 but closed because of the increasing number of specialized journals. Currently, the most influential academic journals in finance are the Journal of Finance (JOF), which began publishing in 1946; the Journal of Financial Economics (JFE), which began in 1974; and the Review of Financial Studies (RFS), which began in 1987.

Developed countries are ahead regarding the impact of journals as observed in other fields of science. Merigo and Yang (2014), in investigating the number of articles published, citations, and $\mathrm{H}$-indices of the most influential finance journals (JOF, JFE, RFS and Journal of Financial and Quantitative Analysis (JFOA), determined that the United States, with two-thirds of the articles and $50 \%$ of the citations in these publications, was the most productive country, with Canada coming in at a distant second and England third. Despite ranking 25th, Turkey closely followed the developed countries. Only India as a developing country ranked higher than Turkey. Hsu and Chiang's (2015) bibliometric analysis of financial-crisis papers published in SSCl-indexed journals between 1926 and 2013 found the United States and England at the top, while Turkey ranked 16th. 
Bibliometric analyses of scientific studies generally analyze the articles published in a single journal. By contrast, this study provides a comparative bibliometric analysis between two top finance journals, the Journal of Finance (JOF) and the Review of Financial Studies (RFS), and two Turkish journals: the Journal of Economics, Business and Finance and the Journal of Accounting and Finance (Mufad).

The rest of this article is organized as follows: Section 2 consists of a literature survey; Section 3 explains data and methodology; Section 4 describes empirical findings; and Section 5 details conclusions.

\section{LITERATURE SURVEY}

To perform a comparative bibliometric analysis of finance research articles in the selected academic journals, this study uses as measures research collaboration, author self-citation, average number of pages, average age of references, and JEL categories. One feature that makes this study unique is that it provides a comparative analysis of articles in developing countries like Turkey and those of developed countries.

Except for the JEL category analysis, the analyses are performed for all of the papers in the journals mentioned. Journal of Finance articles are not included in the JEL comparison, as the publication does not contain JEL codes. The literature overview relating to the measures used in the study includes research collaboration, number of self-citations, average number of pages, average number of references, average age of references, and JEL category analysis.

\subsection{Research Collaboration}

Katz and Martin (1997) describe a research collaboration as consisting of researchers coming together with the common purpose of producing new scientific knowledge. The number of authors on economics papers has increased in recent years. Kosnik (2015) used the social network effect to explain this increase, because multiauthorship decreased social distance among the authors.

Rijnsoever and Hessels (2011) argued the following as collaboration motivations among the authors included in their literature search: accessing expertize and instruments, efficiency of interdisciplinary study, increasing funding opportunities, gaining prestige and visibility, and forming a knowledge repository to overcome large, complex problems.

Katz and Martin (1997) found that, among the analyzed institutions on a national basis, at least $5 \%-15 \%$ of the studies were collaborative. Rath and Wohlrobe (2015) determined an increase in collaborative publications, including 700,000 papers on economics in RePEc between 1991 and 2013. Guerrero-Baena et al. (2014) determined that $83 \%$ of the 347 business finance articles in the Scopus database had two or more authors for the period between 1980 and 2012. Alkan and Ozkaya (2015) calculated that $84 \%$ of the research by Turkish academicians in $\mathrm{SSCl}$ between 1980 and 2014 was multi-authored.

Researchers have observed different results regarding the value of the research collaboration. For example, Avkiran (1997) claimed that research collaborations in the finance field did not generate more quality articles and that there was no significant difference between the number of citations in multi-author papers and those in single-author papers. On the contrary, Gazni and Didegah (2011) found a significant correlation between the number of institutions that contributed to publication and citation frequency in the publications of Harvard University Press between 2000 and 2009, showing that the larger the number of institutions involved, the more normalized the average citation frequency. Levitt (2015) observed that in 19 social science disciplines, articles with at least two authors caused a significant positive citation effect for all the disciplines, although additional authors only had an impact on certain disciplines. However, the finance studies with up to three authors increased the number of citations.

\subsection{Number of Self-Citations}

Author self-citation and its role in the scientific production process have polarized the academic world. Some parts of the scientific world see self-citations as a tool that artificially empowers the author's position in the science community by increasing the citations. However, bibliometric specialists tend to accept reasonable author self-citation as a natural part of scientific communication (Glanzel et al., 2004). 
Aksnes (2003) claims in his most-cited study that the least-cited articles have the most author self-citations and that a strong positive correlation exists between the number of authors and the number of author selfcitations. Fowler and Aksnes (2007), examining more than half a million citations of articles by Norwegian scientists, determined that, statistically, no significant difference existed between author's stock of selfcitation and the number of the citations of the authors' subsequent research.

Seeing self-citations as the product of authors' deceptive approaches will be a prejudiced outlook, because authors often must cite their previous research, on which they have built their new work, for other academicians who work in a related field and direction.

\subsection{Average Number of Pages}

The page number of a study is one of the considered variables in the bibliometric analysis. Kosnik (2015) has assumed that articles with more pages examine subjects more deeply. However, its use as a measure is limited. Because of different page limits and page dimensions and font sizes of each journal force the use of different methods to evaluate the number of pages. Thus, the alternative method for comparing the number of pages in papers is to analyze the trend in the number of pages by years rather than counting the number of pages for the period.

Card and Vigna (2013) examined the most qualified five economic journals between 1970 and 2012 and found that the number of pages per article increased in all fields over the past 40 years. Falagas et al. (2013) claimed a positive relation between the paper's length, the citation number, and the impact factor, because the methodology and findings of the study are presented and discussed in detail. Habibzadeh and Yadollahie (2010) reached the same result regarding citations, also advising that editors revise their views on limiting the number of pages. In one of the rare studies in the field of accounting and finance in Turkey, Hotamisli and Erem (2014) found that between 2005 and 2013 the number of pages varied between 10 and 17 in the Journal of Accounting and Finance.

\subsection{Average Number of References}

Garfield (1979) mentions that the average number of references in an article in a specific area is the most correct criterion for measuring the citation potential. However, the quality of the references are also important. Indeed, Marx and Bornmann (2015), examining the Web of Science database for the years 1990, 1995,2000 , and 2005 , demonstrated that the number of references during these years multiplied, affecting the average number of citations registered to the database of Web of Science. Ucar et al. (2014) found 8 references in 1972 and 25 references in 2013 in their analysis of 8 engineering journals, observing that, especially during the 2000s, the increasing number of search engines in turn increased this number rapidly. Glanzel and Schoepflin (1999) determined the average number of references as 20.8 in papers in business fields. Uzun (1998) examined Turkish-addressed studies between 1987 and 1996 and found that each article contained, on average, 24 references.

\subsection{Average Age of References}

Bibliometric analysis in the literature uses reference age to indicate whether articles follow current studies and last findings. Lariviere et al. (2008) has found that in studies on the Thomson Scientific database between 1900 and 2004, the average age of literature has increased consistently since the early 1970 s.

Glanzel and Schoepflin (1999) calculated the average age of the references in the field of business as 10.9 years. Schäffer et al. (2011) claimed that finance research has followed new researches closely, in a study including the bibliometric analysis of the most qualified four finance journals that focused on the age of citations between 1988 and 2007,

\subsection{JEL Category Analysis}

The JEL category system simplifies research via universal classification of economics studies. Cornelius and Persson (2006) observed that researchers in the field of finance were likelier to use quantitative methods. Guerrero et al. (2014) found that in business finance research, capital budgeting was the most studied area, 
leading other fields by $64 \%$. Schäffer et al. (2011) observed that three out of four studies in the field of finance were classified by the following JEL codes: asset pricing, market microstructure, proxy conflict, initial public offering, financial intermediation, and term structure represented three out of four of the studies in the field. The authors also determined a concern regarding domestic capital markets, law-finance relations, and investment funds.

Examining the accounting and finance articles in the Journal of Faculty of Business of istanbul University of Turkey between 1972 and 2007, Sakin (2008) found that business finance, security management, and financial markets were the top three JEL classifications. Hotamisli and Erem (2014) observed that authors of finance papers published in Mufad used the JEL classifications of financial performance, public economy, and financial markets.

\section{DATA AND METHODOLOGY}

This study compares the finance articles published in the highest-impact journals with those of developing country-addressed journals from a bibliometric perspective, because bibliometry in particular has recently started to direct science and technology policies of the institutions and countries (Zan, 2012). For this purpose, as a case, this study compares papers published in Turkey-originated journals with those published in the highest-impact journals. The authors of this study expect this comparison between articles by foreign and Turkish academicians to show the degree to which studies of finance published in Turkey conform with those published worldwide. In this regard, this study performs a comparative bibliometric analysis of 999 finance articles published between 2010 and 2014 in the Journal of Finance (JOF), Review of Financial Studies (RFS), Economics, Business and Finance (IIF) and the Journal of Accounting and Finance (Mufad). Table 1 shows the statistics of the articles as analyzed by year.

Table 1: The Number of the Finance Articles Published in Four Journals by the Years

\begin{tabular}{lrrrrrr}
\hline & $\mathbf{2 0 1 0}$ & $\mathbf{2 0 1 1}$ & $\mathbf{2 0 1 2}$ & $\mathbf{2 0 1 3}$ & $\mathbf{2 0 1 4}$ & \multicolumn{1}{c}{ TOTAL } \\
\hline JOF & 69 & 60 & 60 & 67 & 71 & 327 \\
RFS & 122 & 107 & 95 & 83 & 93 & 500 \\
IIF & 9 & 11 & 10 & 16 & 11 & 57 \\
MUFAD & 33 & 20 & 20 & 21 & 21 & 115 \\
TOTAL & 233 & 198 & 185 & 187 & 196 & 999 \\
\hline
\end{tabular}

The following paragraphs specify the characteristics of the journals analyzed.

Journal of Finance (JOF): This journal has been determined as the most prestigious finance journal for the study period 2010-2014, according to the weighted citation index (SJR) of the SCImago Journal \& Country Rank, a portal that includes the journals and country scientific indicators developed from the information contained in the Scopus database (Elsevier B.V.). The journal is also a part of the American Finance Association.

Review of Financial Studies (RFS): The RFS, published by Society for Financial Studies (SFS), ranks second behind the Journal of Finance in importance according to the SJR for the study period 2010-2014.

Journal of Economics, Business and Finance (IIF): The IIF is one of the few Turkish journals indexed in SSCI within the analysis period, chosen for its comparability in the index context with the two most influential journals in the world.

Journal of Accounting and Finance (Mufad): This Turkish journal has provided an important platform in Turkey for academic studies in the field of accounting and finance for about 17 years, as field index searches indicate. Published by the Science and Research Association of Accounting and Finance Academicians, Mufad is similar to the Journal of Finance and Review of Financial Studies in its affiliation with an association. 


\section{EMPIRICAL FINDINGS}

\subsection{Analysis of Research Collaborations with Non-Educational Institutions}

Figure 1 shows that the Turkish publication IIF published almost three times more number of collaborative studies with non-educational institutions like central banks, research centers and other government agencies as did JOF and RFS. Mufad, another Turkish journal, published far below the average of the other three journals regarding academic and non-academic collaborations.

Figure 1: Average Share of Authors From Non-Educational Institutions

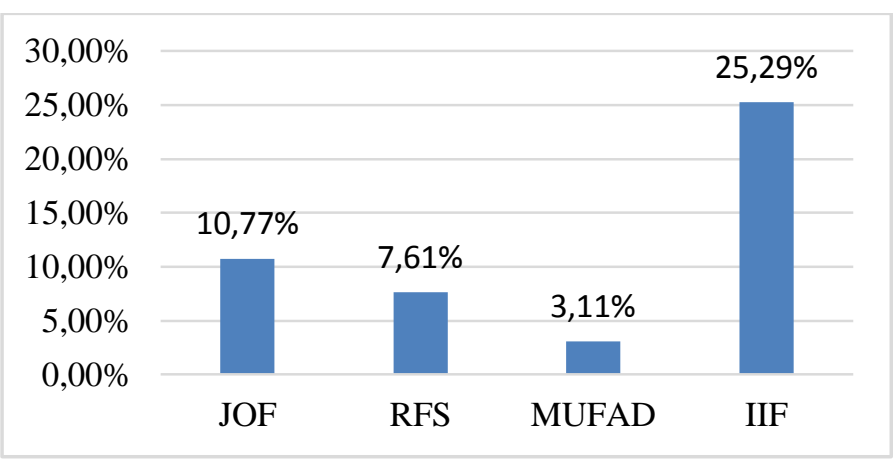

Figure 2 shows that inter-institutional collaboration varied between $5 \%$ and $10 \%$ in JOF and RFS between 2010 and 2014; despite fluctuations in Turkish journals, the overall trend is increasing.

Figure 2: Average Share of Authors From Non-Educational Institutions by Year

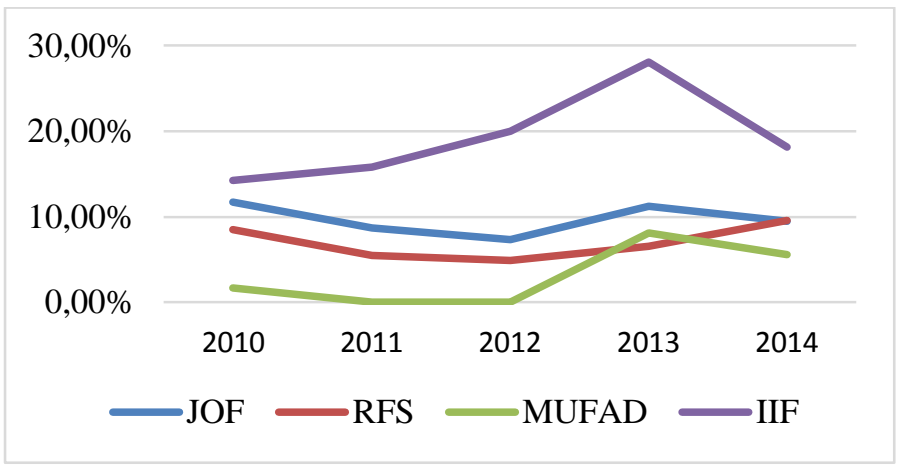

\subsection{Analysis of Number and Composition of Authors}

Figure 3 shows that the number of authors in JOF and RFS was greater than that in the Turkish journals. 
Figure 3: Average Number of Authors

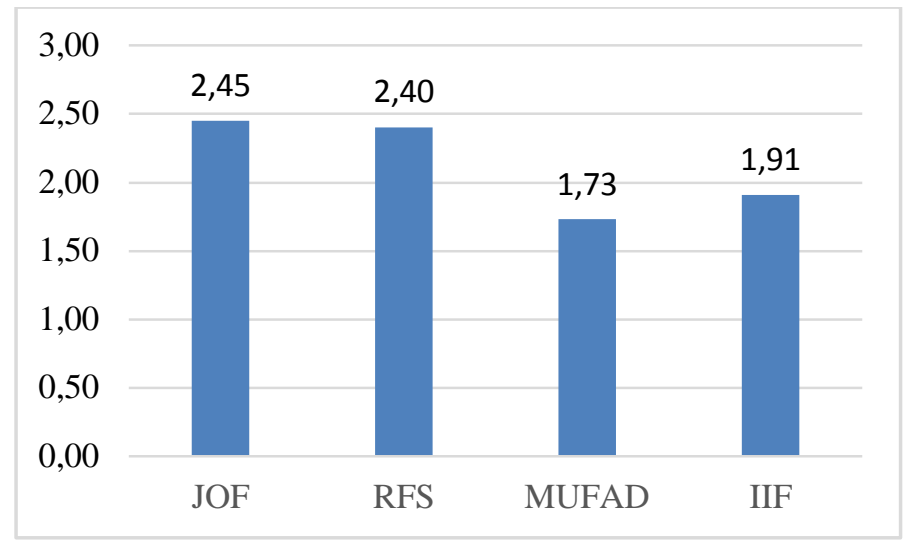

Figure 4 shows that the average number of authors in JOF and RFS fluctuated around 2.50 in the best journals during the study period, while the average number of authors in Turkish journals moved in a relatively narrow range.

Figure 4: Change in Average Number of Authors by Year

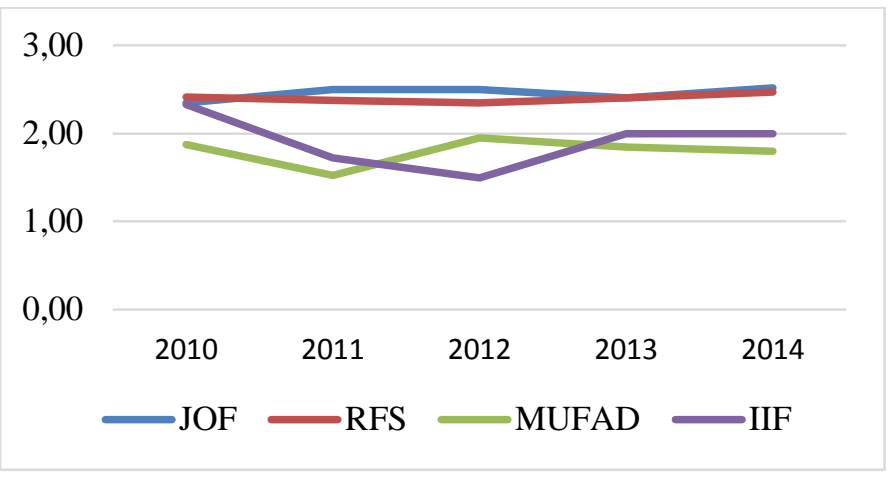

Figure 5 shows that Turkish female academicians made two times more contributions to the field than did female authors in the developed countries. When one considers that the ratio of the female academicians in Turkey is $43 \%$ as of 2014 (Oktay, 2014), 35\%-40 \% in the United States, and 30\%-40\% in the EU as of 2013 (Times Higher Education, 2013), one may conclude that the Turkish academic world is in a highly developed position regarding gender composition. However, Figure 6 shows that while the number of female authors published in Turkish journals has fluctuated over the years. But a decline is also observed in the appearance of female researchers in the Turkish journals. The two leading global journals demonstrate a slow but steady increase in the number of female researchers. 
Figure 5: The Share of Female Authors

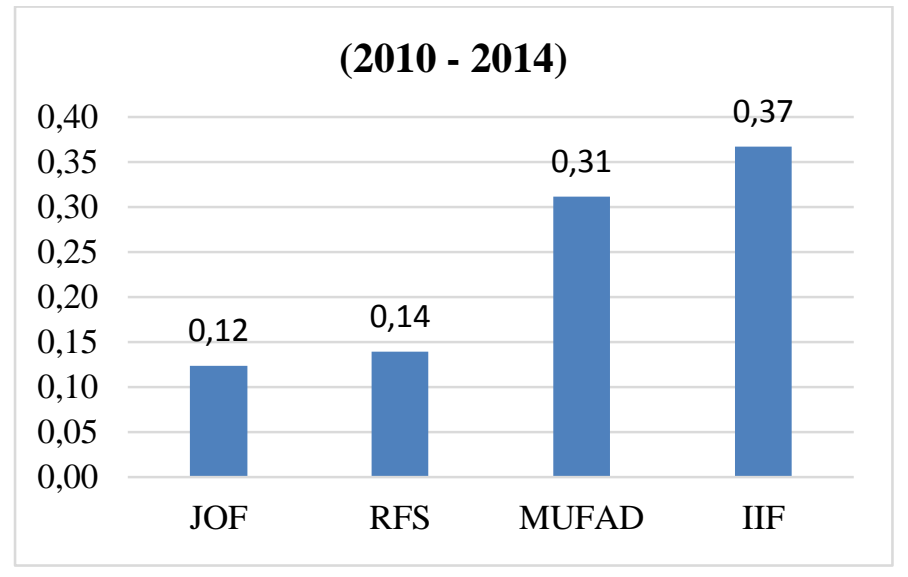

Figure 6: Change in Number of Female Authors by Year

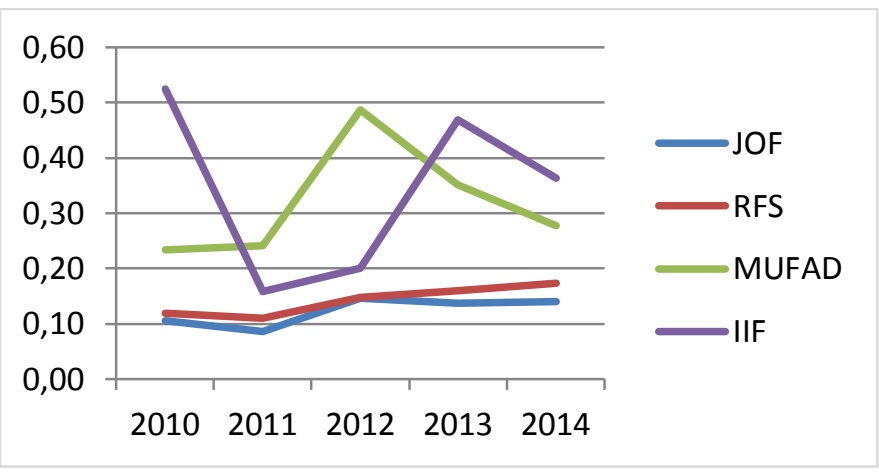

\subsection{Analysis of Average Number of Pages}

As mentioned before, author instructions, the number of page limit and font size of the journals are different. Accordingly, these limitations should have been taken into consideration with regard to the analysis of the number of pages. While Mufad and IIF journals both have a 25-page limit, JOF's page limit is 60, and RFS has no limit.

As seen in Figure 7, the number of pages of per article in all journals increased over the 2010-2014, but the increase in number of pages per article was relatively significant in the Turkish journals compared to the other two journals. Hence, the number of pages of articles in Mufad increased from 13.84 to 18.50 and the number of pages per article in IIF increased from 20.89 to 26.09 . 
Figure 7: Change in Number of Pages per Article (2010=100)

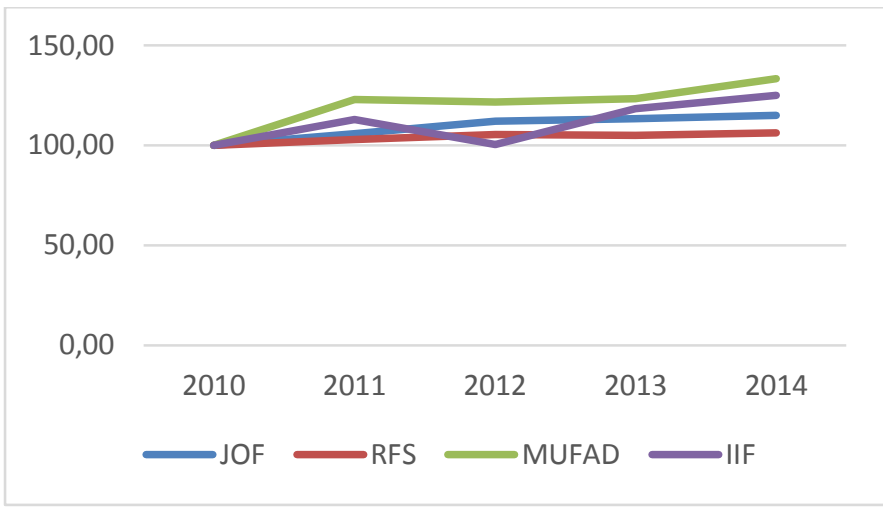

\subsection{Analysis of the Average Number of References}

This section describes the analysis of the 44,576 references in the finance articles published between 2010 and 2014. Table 2 provides the distribution of the number of references to journals and years.

Table 2: The Number of References in the Finance Articles

\begin{tabular}{|c|c|c|c|c|c|c|c|}
\hline & 2010 & 2011 & 2012 & 2013 & 2014 & \multicolumn{2}{|l|}{ Total } \\
\hline JOF & 3316 & 2588 & 2959 & 3098 & 3493 & \multicolumn{2}{|l|}{15454} \\
\hline RFS & 5832 & 5104 & 4414 & 4023 & 4532 & \multicolumn{2}{|l|}{23905} \\
\hline \multicolumn{2}{|c|}{ MUFAD } & 769 & 494 & 469 & 541 & 627 & 2900 \\
\hline IIF & 333 & 395 & 348 & 623 & 618 & 2317 & \\
\hline Total & 10250 & 8581 & 8190 & 8285 & 9270 & 44576 & \\
\hline
\end{tabular}

Articles in the two most influential journals averaged 47 references, which IIF, of the two Turkish journals, managed to approach.

Figure 8: Average Number of References

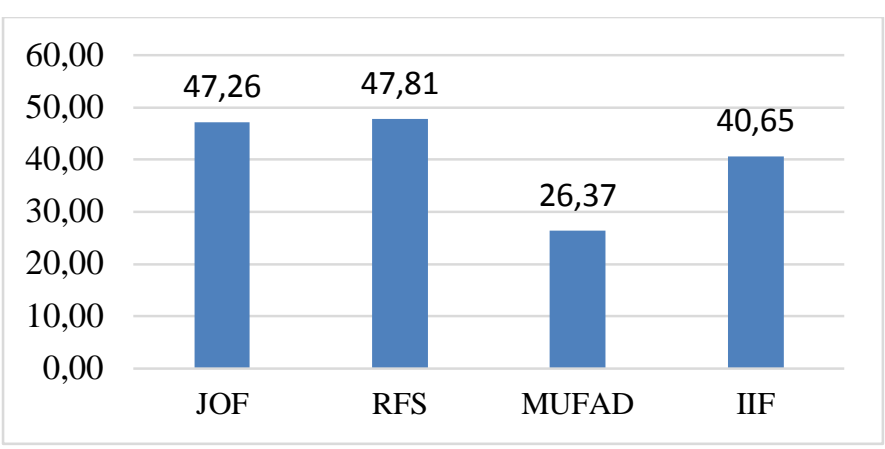

Nonetheless, as Figure 9 shows, the number of references in the articles published in the Turkish journals demonstrated a relatively steady increase. When one takes into account the averages of 2014, the IIF journal ranked first with 56 references. 
Figure 9: Change in Average Reference Number by Year

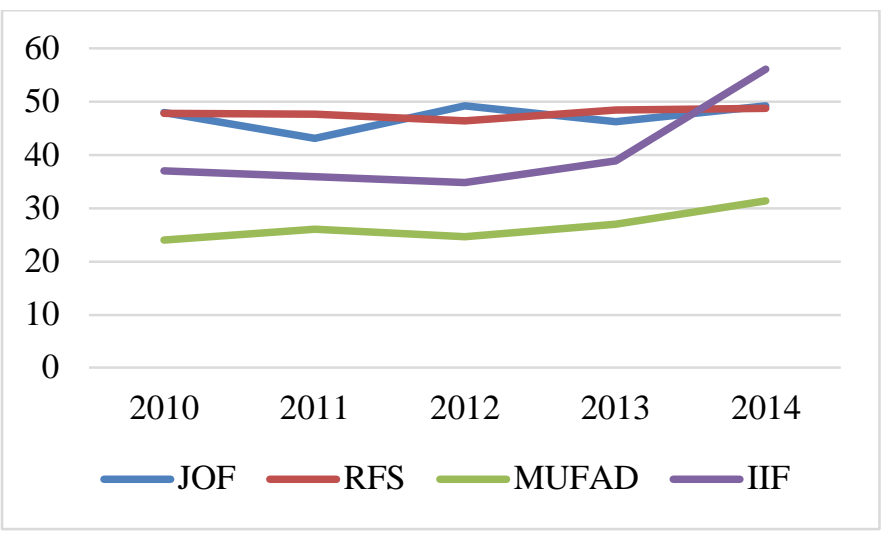

\subsection{Analysis of Self-Citation}

The number of self-citations (approximately 2.4) in the most qualified journals during the study period is extremely high compared with the articles published in Turkish journals. While the Turkish journal IIF demonstrated improvement in the area of self-citation, the self-citation number in Mufad decreased significantly, as Figure 11 shows.

Figure 10: Average Number of Self-Citations

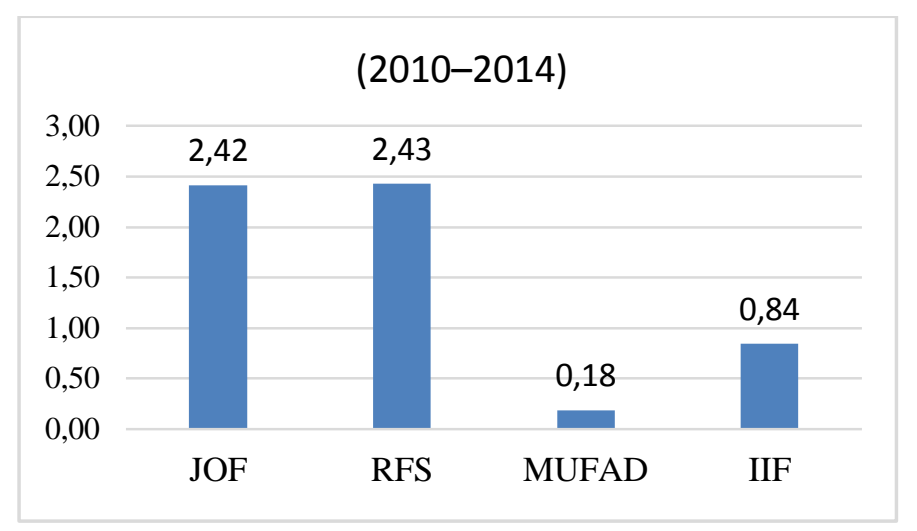

Figure 11: Change in Self-Citation Numbers By Year

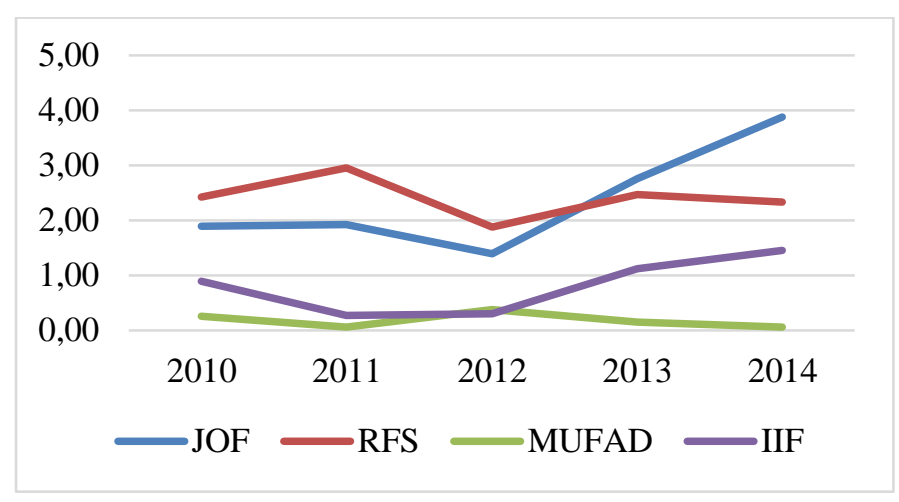




\subsection{Average Age of References}

The average reference age of an article in the study is calculated as the average of the difference between the article's publication year and the publication year of each of the references it cites and then the average age of references of each paper is calculated. While the average reference age of the three journals (JOF, RFS, and IIF) is 11.8 years, Mufad has the youngest reference age with 9 years. These findings are compatible with those of Glanzel and Schoepflin (1999), who have found that the average age of references in the business field is 10.9 years. JOF, RFS and IIF journals approach this age range.

Figure 12: Average Reference Ages of Journals

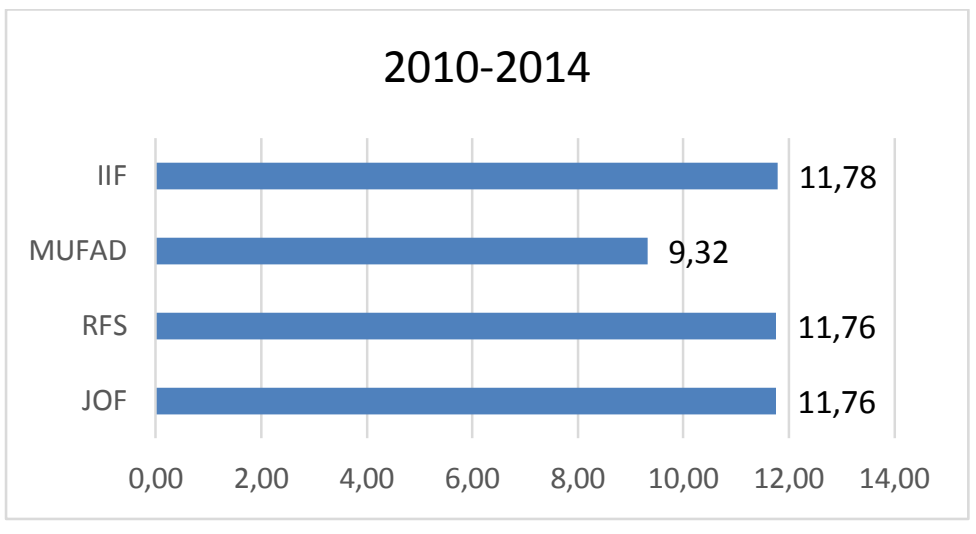

\subsection{JEL Category Analysis}

This study includes JEL categories exceeding $5 \%$ of all categories in a year of the journal. Because Journal of Finance articles do not contain JEL codes, this comparison does not include them. Figure 13 shows the share of the JEL categories within the study period.

\section{Figure 13: Share of JEL Categories}

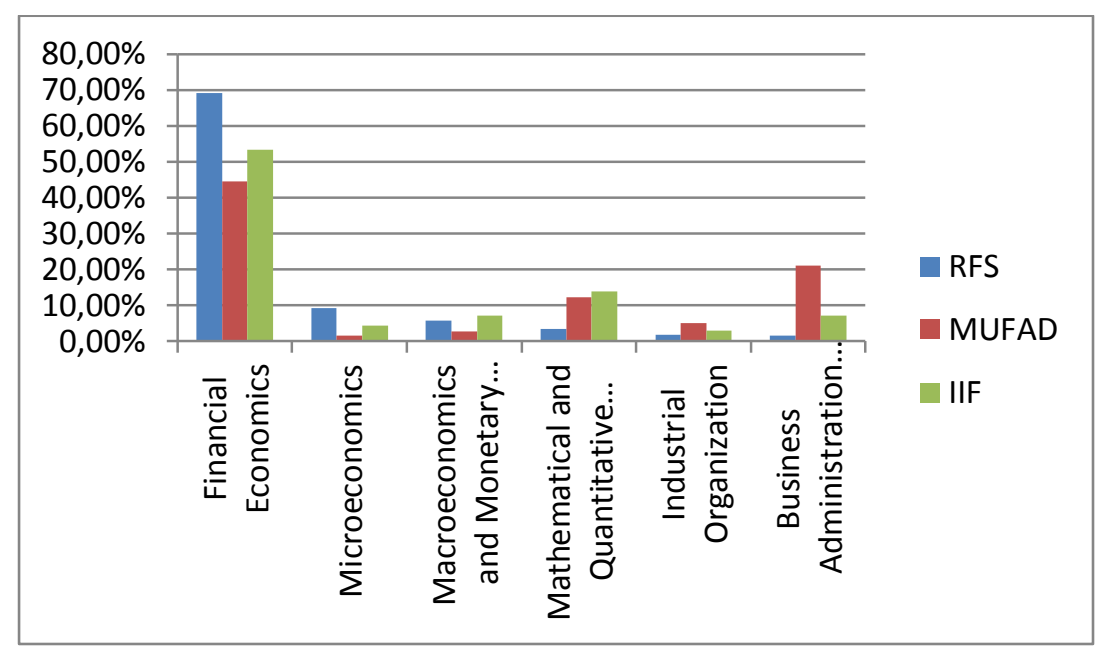

The most studied field among the articles published in all of the selected journals is financial economics. However, articles in Turkish journals on financial economics lag far behind the Western journals. Another significant result is that Western journals contain a much greater number of microeconomics studies than do Turkish journals. Finally, Turkish journals publish articles detailing mathematical and quantitative methods at a far higher rate than do foreign journals. 
It is also important to determine the subcategories studied in financial economics as the most studied category. Table 3 shows the distribution of financial economics subfields over the five years included in the analysis.

Table 3: Subcategories of the Financial Economics

\begin{tabular}{|c|c|c|c|}
\hline & MUFAD & IIF & RFS \\
\hline G01: Financial Crises & $\bullet$ & & \\
\hline G10: General (Financial Markets) & $\bullet$ & & \\
\hline G11: Portfolio Choice, Investment Decisions & $\bullet$ & $\bullet$ & \\
\hline G12: Asset Pricing, Trading Volume, Bond Interest Rates & $\bullet$ & $\bullet$ & \\
\hline G14: Information and Market Efficiency, Event Studies, Insider Trading & $\bullet$ & $\bullet$ & \\
\hline G15: International Financial Markets & $\bullet$ & $\bullet$ & \\
\hline G21: Banks, Depository Institutions, Micro Finance Institutions, Mortgages & $\bullet$ & $\bullet$ & $\bullet$ \\
\hline G28: Government Policy and Regulation & $\bullet$ & & \\
\hline G30: General (Corporate Finance and Governance) & $\bullet$ & & \\
\hline G32: Financing Policy, Financial Risk and Risk & $\bullet$ & & e \\
\hline \multicolumn{4}{|l|}{ Management, Capital and Ownership Structure, } \\
\hline Firm Value, Goodwill & & & \\
\hline
\end{tabular}

As Table 3 shows, while the articles published in the RFS, one of the most prestigious journals following the recent studies, focused on just three subcategories, the articles in IIF and Mufad were distributed around eight subcategories and six subcategories respectively. Among the three journals, banks, financial institutions accepting deposits, microfinance institutions and mortgage (G21) categories were the common subcategories.

\section{CONCLUSION}

This study aims to investigate differences between papers in high-impact journals and developing countryoriginated journals in the field of finance by comparing two Turkish journals with two leading global highimpact journals. The results are as follows.

In both Turkish journals, publication of collaborative research is an increasing trend. But while the one indexed in $\mathrm{SSCl}$ included more collaborative studies compared with the highest-impact journals, the other Turkish journal published far fewer collaborative studies, on average, than the other three journals.

Although the average number of authors in Turkish journals was smaller than the average in the highest-impact journals, Turkish female academicians made more contributions to finance literature.

The average article length in Turkish journals has been increasing in recent years relative to the high-impact journals. It is possible to claim that Turkish studies have gained depth.

Turkish journals remained behind the two highest-impact journals with regard to the number of the references in the articles published, even though the average number of references in Turkish publication articles has been increasing steadily.

The number of self-citations in articles published in the most-qualified two journals were extremely high when compared with the articles published in the Turkish journals.

While the average age of references in the SSCl-indexed Turkish journal is around that of the high-impact journals, the non-SSCl-indexed Turkish journal had the youngest average references.

Financial economics is the JEL category most often selected for articles published in the selected journals. However, the number of studies in the category of financial economics in the Turkish journals remained far behind those in the Western journals. Furthermore, Turkish academicians prefer a wide range of study areas compared with Western academicians, who prefer to narrow their scope of study. 


\section{REFERENCES}

Aksnes, D. W. (2003), A Macro Study Of Self-Citation, Scientometrics, 56(2), p.235-246.

Alkan, G. and Ozkaya, H. (2015), 20 Years Of Turkish Finance And Accounting Literature In SSCI, MUFAD, 66, p.175-192.

Avkiran, N. K. (1997), Scientific Collaboration In Finance Does Not Lead To Better Quality Research, Scientometrics, 39(2), p.173-184.

Card, D. and Vigna, S. D. (2013), Nine Facts About Top Journals In Economics, Journal of Economic Literature, 51(1), p.144-161.

Cornelius, B. and Persson, O. (2006), Who's Who In Venture Capital Research, Technovation, 26, p.142-150.

Falagas, M. E., Zarkali, A., Karageorgopoulos, D. E., Bardakas, V., and Mavros, M. N. (2013), The Impact Of Article Length On The Number Of Future Citations: A Bibliometric Analysis Of General Medicine Journals, PLos One, 8(2), p.1-8.

Fowler, J. H., and Aksnes, D. W. (2007), Does Self-Citation Pay?, Scientometrics, 72(3), p.427-437.

Garfield, E. (1979), Citation Indexing - Its Theory and Application in Science, Technology and Humanities, New York: Wiley \& Sons.

Gazni, A., and Didegah, F. (2011), Investigating Different Types Of Research Collaboration And Citation Impact: A Case Study Of Harvard University's Publications, Scientometrics, 87, p.251-265.

Glanzel, W. and Schoepflin, U. (1999), A Bibliometric Study Of Reference Literature In The Sciences And Social Sciences, Information Processing \& Management, $35(1)$, p.31-44.

Glanzel, W., Bart, T. and Balazs, S. (2004), A Bibliometric Approach To The Role Of Author Self-Citations In Scientific Communication. Scientometrics, 59(1), p.63-77.

Guerrero-Baena, M.D., Gomez-Limon, J.A. and Fruet Cardozo, J. V. (2014), Are Multi-Criteria Decision Making Techniques Useful For Solving Corporate Finance Problems? A Bibliometric Analysis, Revista De Metodos Cuantitativos Para La Economia Y La Empresa, 17, p.60-79.

Habibzadeh, F. and Yadollahie, M. (2010), Are Shorter Article Titles More Attractive For Citations? Cross-Sectional Study Of 22 Scientific Journals, Croation Medical Journal, 51(2), p.165-170.

Hotamışlı, M. and Erem, I. (2014), Bibliometric Analysis Of The Articles Published In Journal Of Accounting And Finance, Muhasebe ve Finansman Dergisi, 16 (63), p.1-19.

Hsu, C.L. and Chiang, C.L. (2015), The Financial Crisis Research: A Bibliometric Analysis, Scientometrics, 105(1), p.161-177.

Katz, J. S. and Martin, B. R. (1997), What Is Research Collaboration?, Research Policy, 26, p.1-18.

Kosnik, L. R. (2015), What Have Economists Been Doing For The Last 50 Years? A Text Analysis Of Published Academic Research From 1960 - 2010, Economics Discussion Papers, No 2015 - 4, Kiel Institute for the World Economy, http://www.economicsejournal.org/economics/discussionpapers/2015-4, Accessed: 10 May 2015.

Lariviere, V., Archambault, E. and Gingras, Y. (2008), Long-Term Variations In The Aging Of Scientific Literature: From Exponential Growth To Steady-State Science (1900-2004), Journal of the American Society for Information Science and Technology, 59(2), p.288-296.

Levitt, J. M. (2015), What Is The Optimal Number Of Researchers For Social Science Research?, Scientometrics, 102, p.213-225.

Marx, W. and Bornmann, L. (2015), On The Causes Of Subject-Specific Citation Rates In Web Of Science, Scientometrics, 102(2), p.18231827.

Merigó, J. M. and Yang, J. B. (2014), Prolific Scholars And Institutions In Finance, CQN Workin Paper, http://www.audytax.mx/wpcontent/uploads/2014/12/Prolific-scholars-and-institutions-in-finance.pdf Accessed: 10 April 2015.

Oktay, S. (2014), Akademisyen Kadın Sayısı Artıyor, Anatolia Agency, http://www.aa.com.tr/tr/egitim/akademisyen-kadin-sayisiartiyor/122057, Accessed: 23 September 2015.

Rath, K. and Wohlrabe, K. (2015), Recent Trends In Co-Authorship In Economics: Evidence From Repec, CESifo Working Paper Series No. 5492, http://papers.ssrn.com/sol3/papers.cfm?abstract id=2663991, Accessed: 21 June 2015.

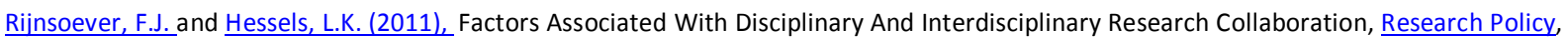
40(3), p.463-472.

Sakin, T. (2008), A Content Analysis Of Papers Published In The Journal Of School Of Business Administration: Accounting And Finance (1972-2007), Istanbul University Journal of the School of Business Administration, 37(1), p.13-21.

Schäffer, U., Nevries, P., Fikus, C. and Meyer, M. (2011), Is Finance Research A “Normal Science"? A Bibliometric Study Of The Structure And Development Of Finance Research From 1988 To 2007, Schmalenbach Business Review, 63(2), p.189-225. 
Times Higher Education (2013), Global Gender Index,

https://www.timeshighereducation.com/sites/default/files/Attachments/2013/04/29/b/g/i/percentage-of-women-in-academia-bycountry.pdf, Accessed: 10 September 2015.

Ucar, I., López-Fernandino, F., Rodriguez-Ulibarri, P., Sesma-Sanchez, L., Urrea-Micó, V. and Sevilla, J. (2014), Growth In The Number Of References In Engineering Journal Of Papers During The 1972-2013 Period, Scientometrics, 98(3), p.1855-1864.

Uzun, A. (1998), A Scientometric Profile Of Social Sciences Research In Turkey, The International Information \& Library Review, 30(3), p.169-184.

Zan B. U. (2012), Türkiye'de Bilim Dallarında Karşılaştırmalı Bibliyometrik Analiz Çalışması, Unpublished Thesis, Ankara Üniversitesi Sosyal Bilimler Enstitüsü, Bilgi ve Belge Yönetimi Anabilim Dalı, Ankara. 